\begin{tabular}{|l|l|l||}
\hline \multicolumn{2}{|c|}{ PublisherInfo } \\
\hline \hline PublisherName & $:$ & BioMed Central \\
\hline \hline PublisherLocation & $:$ & London \\
\hline \hline PublisherImprintName & $:$ & BioMed Central \\
\hline \hline
\end{tabular}

\title{
PAR for the course
}

\begin{tabular}{|l|l|l||}
\hline \multicolumn{2}{|c|}{ ArticleInfo } \\
\hline \hline ArticleID & $:$ & 4686 \\
\hline \hline ArticleDOI & $:$ & $10.1186 /$ gb-spotlight-20030127-01 \\
\hline \hline ArticleCitationID & $:$ & spotlight-20030127-01 \\
\hline \hline ArticleSequenceNumber & $:$ & 38 \\
\hline \hline ArticleCategory & $:$ & Research news \\
\hline ArticleFirstPage & $:$ & 1 \\
\hline \hline ArticleLastPage & $:$ & 2 \\
\hline \hline & & RegistrationDate : 2003-1-27 \\
\hline ArticleHistory & $:$ & OnlineDate \\
\hline \hline ArticleCopyright & $:$ & BioMed Central Ltd2003-1-27 \\
\hline \hline ArticleGrants & $:$ & \\
\hline \hline ArticleContext & $:$ & 130594411 \\
\hline \hline
\end{tabular}




\section{Jonathan B Weitzman}

Email: jonathanweitzman@hotmail.com

In the January 23 Nature Sophie Martin and Daniel St Johnston from the University of Cambridge, UK, show that the Drosophila LKB1 protein, a homolog of the PAR kinases identified for their role in C. elegans embryonic polarity, is required for early anterior-posterior polarity in the fly oocyte (Nature 2003, 421:379-384). They performed a genetic screen for mutants that disrupt the localization of the posterior-polarized protein Stauffen. Genome mapping led them to the $l \mathrm{~kb} 1$ gene, which encodes a serine/threonine kinase homologous to the human tumor suppressor LKB1 and the C. elegans PAR-4 kinase that is involved in embryonic polarity. LKB1 is phosphorylated by the related PAR-1 kinase and by protein kinase A. DrosophilaLKB1 is essential for cell polarity in the germ line and the follicle cells

\section{References}

1. Nature, [http://www.nature.com]

2. University of Cambridge, [http://www.cam.ac.uk]

3. LKB1 - a master tumour suppressor of the small intestine and beyond.

4. The C. elegans par-4 gene encodes a putative serine-threonine kinase required for establishing embryonic asymmetry.

This PDF file was created after publication. 